\title{
VÉDERDŐ TELEPÍTÉSÉNEK LEHETSÉGES JÖVŐBELI HATÁSAI SZEGED HŐTERHELÉSÉBEN
}

\author{
SKARBIT NÓRA - UNGER JÁNOS - GÁL TAMÁS \\ POSSIBLE FUTURE EFFECTS OF THE PROTECTIVE FOREST INSTALLATION \\ ON THE HEAT LOAD IN SZEGED
}

\begin{abstract}
In this study the possible future thermal consequences of a fictional protective forest around Szeged were examined. The aims of this installation are the adaptation to climate change and reducing air pollution. However, the complex effects of local urban climate should be taken into consideration as well. Therefore, the changing of heat load due to the forest was studied by presenting the change of climate indices during the $21^{\text {st }}$ century. In order to simulate the local circumstances of the city, a MUKLIMO_3 local scale model was applied.EURO-CORDEX regional model simulations ensured the climate data for periods 2021-2050 and 2071-2100 using scenarios RCP4.5 and RCP8.5. Our results show that the effect of the protective forest is not favourable in certain parts of the city due to the reduction or block of the ventilation. The forest induces cooling effect mostly during daytime, but the extent of unfavourable effects exceeds the advantages especially at night time.
\end{abstract}

Keywords: climate change, urban climate, climate indices, RCP scenarios

\section{Bevezetés}

Földünk éghajlatának változása napjaink legismertebb problémakörévé válik, hiszen egyre inkább érezzük ennek a folyamatnak a hatásait mindennapi életünk során. Gondolhatunk a szélsőséges időjárási események gyakoriságának növekedésére (pl. nyári hőhullámok) vagy az évi csapadékmennyiség egyre egyenlőtlenebb eloszlása miatti aszályos vagy belvizes időszakok növekedésére (MEzősı G. et al. 2017). A globális átlaghőmérséklet a 21. század első két évtizedében (2001-2020) 0,99 C-kal volt magasabb, mint az 1850-1900 időszakban és ez a különbség a 21. század végére a legpesszimistább szcenárió szerint már 3,3 és 5,7 ${ }^{\circ} \mathrm{C}$ között lehet (IPCC 2021).

A klímaváltozás folyamata mellett figyelembe kell vennünk azt is, hogy a Föld lakosságának legnagyobb része városokban él és ez az arány a jövőben növekedni látszik, az előrejelzések szerint 2050-re elérheti a 66\%-ot is (UN 2015). A városokban egy helyi sajátos éghajlat (városklíma) alakul ki a beépített, mesterséges környezet és az emberi tevékenység következtében (UNGER J.-GÁL T. 2017). Ennek a speciális éghajlatnak a legfontosabb aspektusa a vidéki területekhez képest megnövekedett hőtöbblet, az úgynevezett hősziget jelenség, amely az éjszaka során éri el maximális intenzitását (SüMEGHY Z.-UNGER J. 2003; OKE, T. R. et al. 2017). Ez a lokális léptékű hőmérséklet módosulás hozzáadódik a globális és regionális klímaváltozás folyamatához, amely a jövőben a hôterhelés jelentős megnövekedését eredményezheti a városokban.

Ennek következtében egyre inkább megnő az igény a városok hőterhelésének csökkentésére, így a különböző klímaadaptációs technikák alkalmazására. Ez lehet a beépítés jellegének megváltoztatása, magasabb albedójú felületek alkalmazása vagy a városi zöldfelületek növelése (IPCC 2014). Utóbbi többféle módon is megvalósulhat, amelyek közül az egyik lehetőség lehet az ún. véderdő vagy véderdő-sávok telepítése. Ez a kezdeményezés előremutató lehet, azonban a városok összetett éghajlata miatt a városklimatikus hatásokat is célszerú figyelembe venni az ilyen és ehhez hasonló tervek kapcsán. 
Célunk az, hogy megvizsgáljuk Szeged, azaz egy közepes méretű város esetén egy úgynevezett véderdőnek, azaz a várost körülvevő erdősávnak milyen klimatikus hatásai lehetnek, különös tekintettel a városban jelentkező hőterhelésre. Kutatásunkban az alábbi kérdésekre keressük a válaszokat:

1) hogyan módosítja a nappali, illetve az éjszakai hőterhelést a véderdő telepítése;

2) a város mely részeit érinti a legnagyobb mértékú változás, valamint

3) a telepítés okozta előnyök meghaladják-e az esetleges hátrányokat.

Ennek során egy rendkívül sematikus és kevésbé realisztikus erdőtelepítés hatását szimuláljuk egy lokális klímamodell segítségével. Ez a megközelítés nem alkalmas közvetlenül arra, hogy részletes várostervezési munkát támogasson, hiszen egy ilyen méretû erdósítés a gyakorlatban feltehetőleg nem valósítható meg, azonban egyértelmúen kimutathatóvá teszi a lépés hatására történő változások trendjeit. Vizsgálatunkban klímaprojekciók eredményeit használjuk fel, így eredményeink a közeli és a távolabbi jövőre vonatkozóan mutatják be a várható hatásokat.

\section{Elméleti háttér}

A városok területén a fásítás egy széleskörben ismert és elfogadott klímaadaptációs lehetőség, hiszen a városi fák kedvező hatásai közül kiemelkedik a hőmérsékletcsökkentő tulajdonságuk. A megfelelő növényzet a közterületek árnyékolására elengedhetetlen a hőstressz csökkentése szempontjából (DE ABREAU-HARBICH, L. V. et al. 2015). Továbbá a városi vegetáció fontos szerepet játszhat a városi hősziget csökkentésében is, amely hatás nem csak a fák, hanem annál magasabb szinteken is megjelenik (WANG, Y.-AKBARI, H. 2016). A fák telepítésénél azonban érdemes számításba venni a régió uralkodó szélirányait, így a fák elrendezésének figyelembevételével növelhető az átszellőzés (ABDI, B. et al. 2020). Emellett fontos szerepet játszik a fák lombkoronájának nagysága (TAN, Z et al. 2016) és az, hogy a fák lombkoronái ne legyenek átfedésben és ne blokkolják a légmozgást (ZHAO, Q. et al. 2018).

Emellett fontos a városi fáknak a légszennyező anyagok, illetve por elleni védőhatása, amelynek mértékét több tényező is befolyásolhatja. Ahhoz, hogy a légszennyezés csökkentése megfelelő mértékű legyen, elsődleges a fák mérete (YANG, J. et al. 2005). A levegőminőség javításának érdekében érdemes a lombkorona méretét növelni, aminek következtében a városi fák nagy mennyiségú légszennyező anyagot tudnak megkötni (NowAK, D. J. et al. 2006). Azonban SETÄLÄ, H. et al. (2013) szerint a városi vegetáció ezen előnye nem számottevő a hidegebb éghajlatokon, mivel itt szignifikánsan nem csökkenti a légszenynyező anyagok mennyiségét a rövid vegetációs időszak.

Több magyarországi település esetében is felmerült ötletként véderdő, illetve véderdősáv telepítése. GÁLOSI-KovÁcS B. (2009) a környezettudatos kistérségfejlesztés egyik lehetséges eszközei közé sorolja a zöldfelületek és zöldterületek kialakítását, amiben példaként a véderdő telepítést is megemlíti. Székesfehérvár városa a környezetvédelmi programjában említi meg a véderdő telepítésének szükségességét. A telepítés fontosságát többek között azzal indokolják, hogy általa jelentôsen csökkenthető a szén-dioxid menynyisége, illetve jelentős lehet a por megkötése [1]. A Hajdú-Bihar Megyei Kormányhivatal Környezetvédelmi és Természetvédelmi Főosztály a zöldterületi fejlesztések között említi a véderdő telepítését. Debrecen városában a fatelepítési programok mellett véderdő-sávok telepítését is tervezik a város nyugati részén. A telepítés okai között a por és légszennyező anyagok megkötése mellett megemlítik a felmelegedés enyhítését is [2]. 


\section{Módszerek}

\section{Lokális klímazónák}

A városi és a városkörnyéki felszín leírása a lokális klímazónák (LCZ-k) alkalmazásával történt (STEWART, I. D.-OKE, T. R. 2012). Az osztályozási módszer széles körben elterjedt a városklimatológiai kutatásokban, hiszen a mesterséges és természetes felszínek különböző típusainak objektív elkülönítését teszi lehetővé (UNGER J. et al. 2014). E típusok elkülönítése a felszín termikus reakcióit leíró fizikai jellemzők alapján történik. Az osztályozási módszer 17 típust (zónát) különböztet meg (1. ábra), ezek közül 10 a beépítettségének, 7 pedig a felszínborításának főbb sajátosságaival jellemezhetô. Elnevezésük egy vagy több megkülönböztető felszínparaméter alapján történik, ami a beépített zónák esetében az épületek magassága, illetve a beépítés sűrúsége, a felszínborítással jellemzett zónák esetében pedig annak jellege.

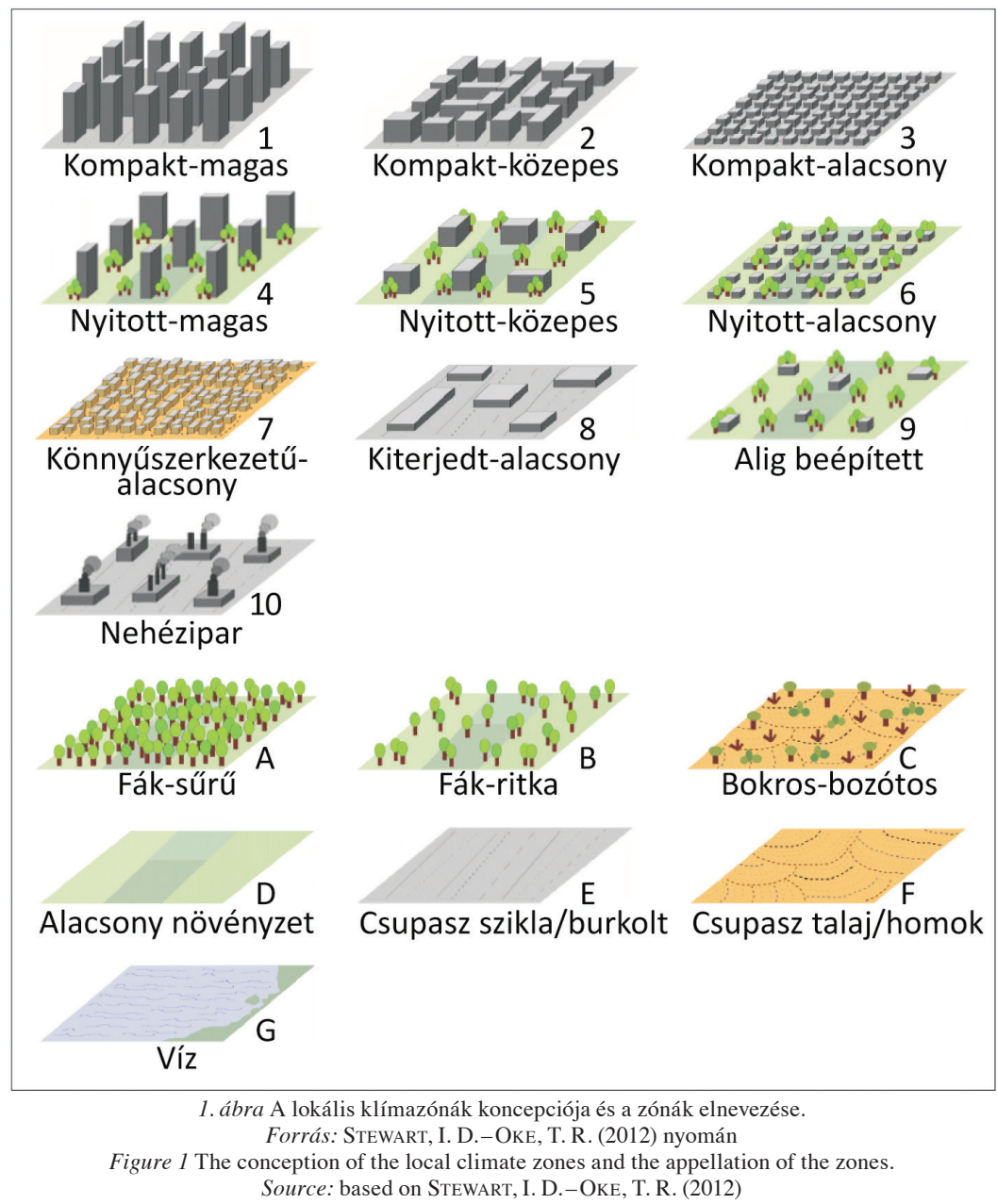


Egy adott terület lokális klímazónáinak meghatározására és térképezésére több módszer is ismert (LELOVICS, E. et al. 2014; LEHNERT, M. et al. 2015). Vizsgálatunkban BECHTEL, B. et al. (2015) módszere alapján történt a zónák térképezése, amelynek előnye, hogy kevés rendelkezésre álló felszínadat esetén is alkalmazható, szabadon hozzáférhető szoftverek segítségével. Az osztályozáshoz szükséges tanulóterületek kijelölése a Google-Earth szoftverben történik, majd az osztályozást a SAGA-GIS használatával hajtható végre Landsat múholdképek felhasználásával.

Szeged és környékének lokális klímazónáit a 2.a ábra mutatja be (SKARBIT, N.-GÁL, T. 2016). Látható, hogy a városközpontban a kompakt beépítés (LCZ 2 és 3), míg a város külső területein a nyitott és alacsony beépítés (LCZ 6,8 és 9) a jellemző. A kompakt közepes beépítés (LCZ 5) egyaránt megtalálható a belső és külső területeken is. A külterület jellemző felszínborítása az alacsony növényzet (LCZ D), míg fás növényzet (LCZ A és B) fóként az árterek mentén jelenik meg.

Jelen vizsgálatunk során módosítottuk a Szeged városhatára mentén jellemző felszínborítást (2.b ábra). A határ mentén egy megközelítőleg 1-2 km-es sávban az alacsony növényzetet (LCZ D) sûrú fás (LCZ A) felszínborítással cseréltük fel. Az erdőterületek kijelölése a város környéki mezőgazdasági területekre korlátozódott, azonban a birtokviszonyokat és más gazdasági jogi szempontokat nem vettük figyelembe, hiszen a szimuláció célja a véderdő lehetséges hatásainak azonosítása.

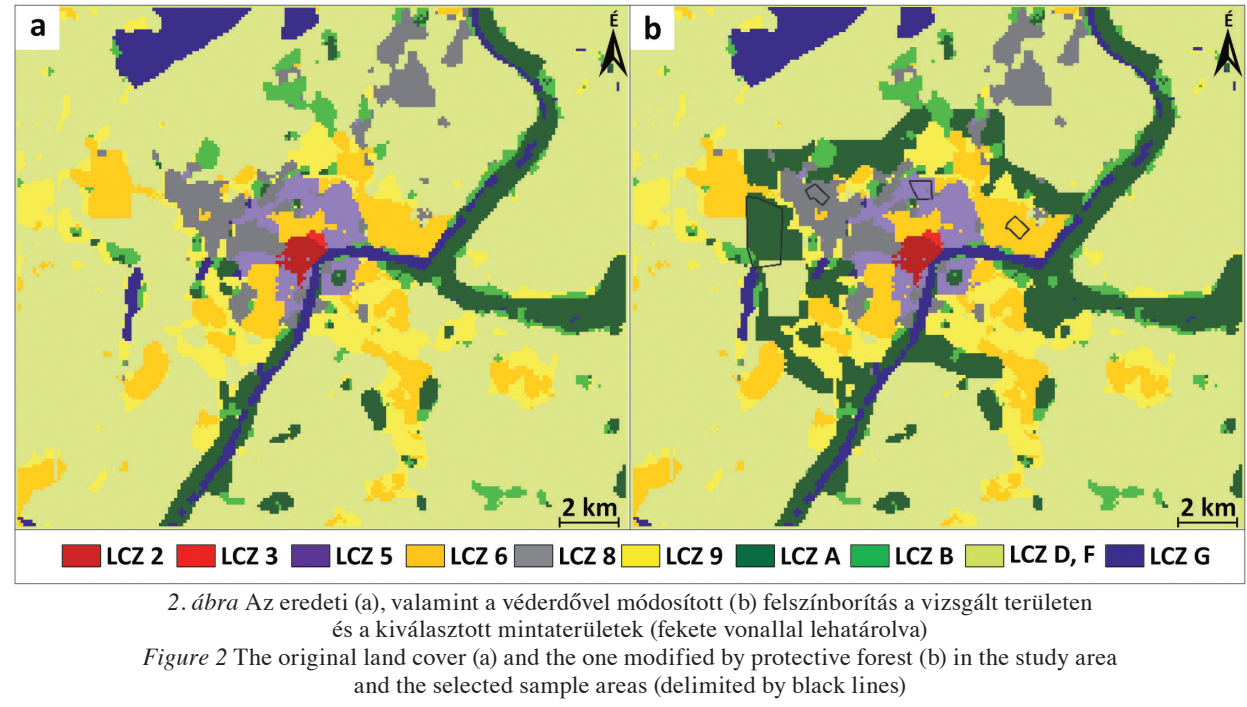

\section{Höterhelés modellezése}

A városi viszonyok leírása a MUKLIMO_3 (SIEvERS, U. 2012, 2016) lokális léptékú klímamodellel történt. A modell a léghőmérsékletet, a légnedvességet és szélviszonyokat szimulálja egy 3 dimenziós rácson. Bemeneti adatokként egy referencia állomás hőmérséklet és légnedvesség profiljai, emellett domborzati és felszínhasználati adatok szükségesek. A horizontális felbontás 100 m-es, míg a vertikális a magassággal változó, a felszín közelében részletesebb, mivel a meghatározó folyamatok itt történnek.

Vizsgálatunkban a hőterhelést klímaindexek használatával számszerúsítettük (1. táblázat). Ezeket az indexeket két 30 éves időszakra számítottuk ki: a közeli 2021-2050-es 
és a távolabbi 2071-2100-asra vonatkozóan. Az ilyen hosszabb időszakok és a kapcsolódó részletes térbeli felbontás együttes alkalmazásának számítási kapacitási igénye igen nagy. Ennek kiküszöbölésére az un. cuboid módszert alkalmaztuk, ami egy trilineáris interpolációs technikának tekinthető (FRÜH, B. et al. 2011; ŽUvelA-AloISE, M. et al. 2014). A módszer azzal a feltételezéssel él, hogy a hőterheléses időszakok speciális időjárási helyzetekben lépnek fel, amelyeket be lehet határolni 8 különböző MUKLIMO_3 szimulációval. Ezeket a szimulációkat két uralkodó szélirányra kell elvégezni, amely Szeged esetében az északkeleti és az északnyugati volt. Emellett a módszerhez egy referencia állomás napi hőmérséklet, relatív nedvesség, szélsebesség és szélirány adatsora szükséges a vizsgált időszakra. Munkánkhoz EURO-CORDEX (JACOB, D. et al. 2014) regionális modellszimulációk Szeged környéki rácspontjainak átlagolt adatsorait használtuk fel, az optimistának tekinthető RCP4.5 és a pesszimista RCP8.5 forgatókönyvekre (VAN VUUREN, D. P. et al. 2011). A modellszimulációkat az alapján választottuk ki, hogy a vizsgálathoz szükséges adatokat tartalmazzák, így 7 különböző futtatás kimeneteit használtuk fel (GÁL, T. et al. 2021). Ezek a szcenáriók a globális átlaghőmérséklet változást $2{ }^{\circ} \mathrm{C}$, illetve $4{ }^{\circ} \mathrm{C}$-ra becsülik a 21. század végére az 1986-2005 időszakhoz viszonyítva (IPCC 2013).

\section{1. táblázat-Table 1}

A vizsgált klímaindexek és meghatározásuk

The examined climate indices and their definitions

\begin{tabular}{ll}
\hline Klímaindex & Definíció \\
\hline Nyári nap & $\left(\mathrm{T}_{\max }>25^{\circ} \mathrm{C}\right)$ \\
Hőségnap & $\left(\mathrm{T}_{\max }>30^{\circ} \mathrm{C}\right)$ \\
Sörkerti nap & $\left(\mathrm{T}_{20 \mathrm{~h}}>20^{\circ} \mathrm{C}\right)$ \\
Nyári éjszaka & $\left(\mathrm{T}_{23 \mathrm{~h}}>20^{\circ} \mathrm{C}\right)$ \\
Meleg éjszaka & $\left(\mathrm{T}_{\min }>17^{\circ} \mathrm{C}\right)$ \\
Trópusi éjszaka & $\left(\mathrm{T}_{\min }>20^{\circ} \mathrm{C}\right)$ \\
\hline
\end{tabular}

\section{Eredmények}

Eredményeink közül részletesebben a felszínborítás megváltozásának hatását a hőségnapok és a trópusi éjszakák számában bekövetkező változásokkal mutatjuk be a 2021-2050 és 2071-2100 közötti időszakokban az RCP4.5 és RCP8.5 szcenárió alapján.

\section{Höségnapok számának változása}

A hőségnapok definíciója (1.táblázat) a napi maximum hőmérsékleten alapul, így alkalmazásával a nappali hőterhelésben jelentkező különbségeket lehet szemléltetni. A 3.ábra a hőségnapok számában bekövetkező változásokat mutatja be a véderdő telepítésének hatására az egyes időszakokban és szcenáriók szerint.

A 2021-2050 közötti időszakban a két szcenárió alapján kapott különbség a hőségnapok számában közel azonos (3.a és b ábra), mivel ebben az időszakban a szcenáriók még nem válnak el jelentősen egymástól (IPCC 2013). A városhatáron belül a legnagyobb növekedés az északi városrészben látható. Ennek oka, hogy az uralkodó északkeleti és északnyugati szelek hatása a véderdő telepítésének következtében korlátozottabban tud csak érvényesülni, így ezeken a területeken a hőségnapok növekedése várható. A legtöbb részen 0 és 
5 nap közötti ez a szám, az érintett területen a jellemző beépítés az LCZ 5, 6 és 8. Látható, hogy több kis területen, jellemzően az LCZ 8 beépítésnél az északnyugati városrészben, 5 feletti különbség is jelentkezhet, köszönhetően annak, hogy ebben a zónában jellemző a magas vízzáró felszínek aránya. Tehát a beépítés jellege is növelheti a véderdő hatására bekövetkező növekedést a hőségnapok számában. Ez megfigyelhető az északkeleti városrészben is, ahol az LCZ 6 és a ritkábban beépített LCZ 9 között is tapasztalható különbség. A város déli részein is jelentkeznek eltérések, főként az LCZ 5 és 6 beépítésnél. A városhatártól északkeletre elhelyezkedő LCZ 8 beépítésú terület esetében is 5 nap feletti különbség léphet fel a véderdő hatására. A hőségnapok jelentősebb, 5 nap feletti csökkenése csak a vízfelszínek közelében várható.

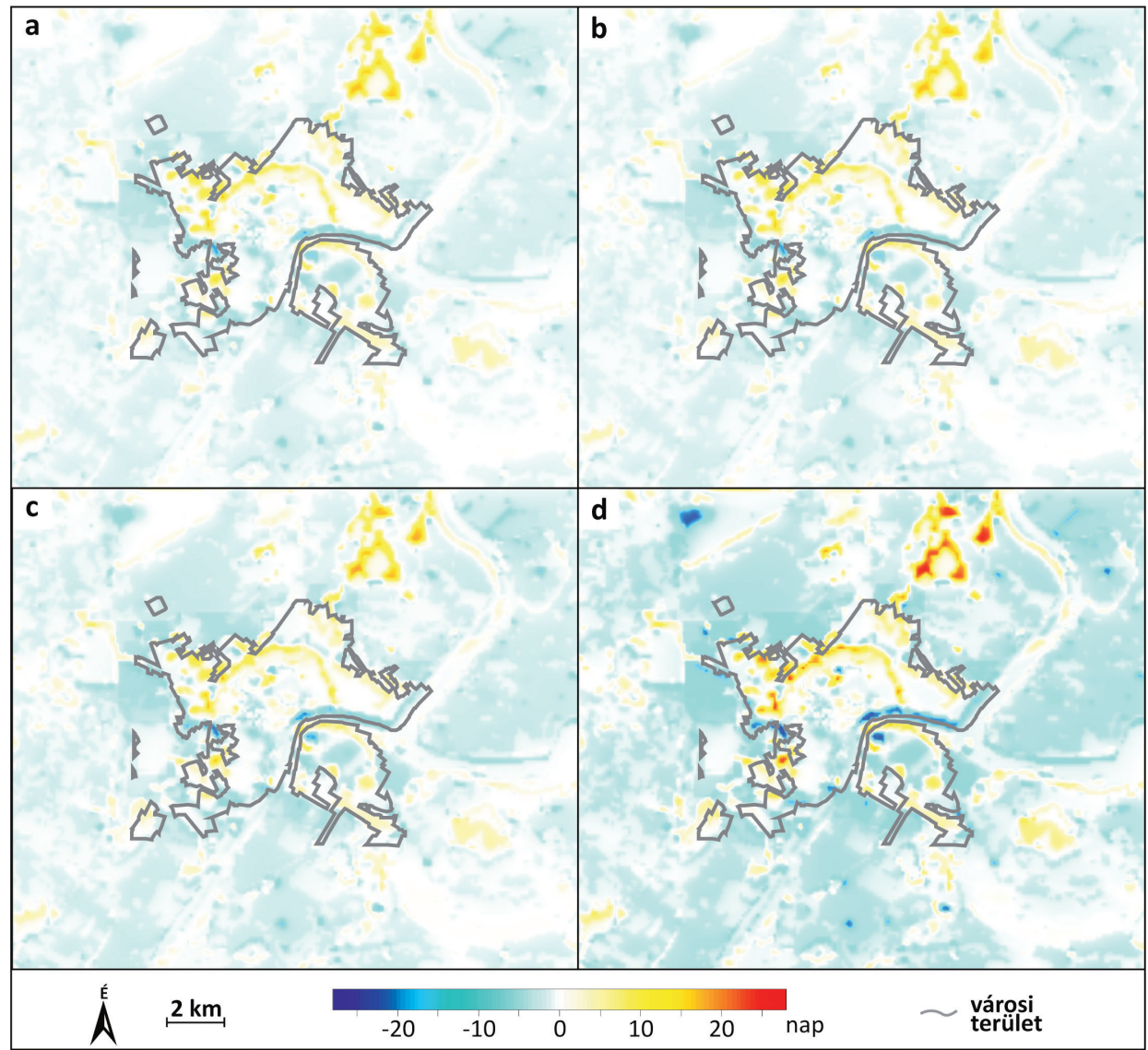

3. ábra A hőségnapok $\left(\mathrm{T}_{\max }>30^{\circ} \mathrm{C}\right)$ számának különbsége a véderdővel módosított és az eredeti felszínborítású vizsgált területek között (a és b: 2021-2050 RCP4.5 és RCP8.5, c és d: 2071-2100 RCP4.5 és RCP8.5)

Figure 3 The difference in the number of hot days $\left(\mathrm{T}_{\max }>30^{\circ} \mathrm{C}\right)$ between the original land use and the one modified by protective forest ( $\mathrm{a}$ and b: 2021-2050 RCP4.5 and RCP8.5, $\mathrm{c}$ and d: 2071-2100 RCP4.5 and RCP8.5)

A 2071-2100 közötti időszakban az RCP4.5 szcenárió szerint (3.c ábra) megjelenő változás közel azonos nagyságrendű az előző időszakban tapasztaltakéval. A pesszimistább RCP8.5 szcenárió alapján (3.d ábra) azonban nagyobb különbségek lépnek fel a véderdő telepítésének hatására, hiszen ebben az esetben a hőségnapok száma már magasabb. Ekkor 
főként a város északnyugati és nyugati részén, nagyobb területen jelentkezik 5 nap fölötti eltérés és több, kisebb területen akár a 10 napot is meghaladhatja. Ezek a nagyobb különbségek elsősorban az LCZ 5 és 8 beépítésú területeken jelennek meg. Látványos változás következhet be a városhatártól északkeletre fekvő LCZ 8 beépítésú területen, ugyanis a terület nagy részén 10 nap feletti eltérés jelenhet meg a véderdő hatására, köszönhetően az északkeleti uralkodó széliránynak. Több területen viszont csökkenhet 5, illetve 10 napot is a hőségnapok száma, jellemzően a vízfelszínek és városhatár mentén, a véderdő területén.

\section{Trópusi éjszakák számának változása}

A trópusi éjszakák definíciója (1. táblázat) a napi minimum hőmérsékletet veszi alapul, így az éjszakai hőterhelés hatása szemléltethető vele. Ez különösen fontos a városi hőtöbblet esetében, hiszen a város és a vidék közötti hőmérsékletek különbsége ebben az időszakban a leghangsúlyosabb. A 4. ábra a véderdő telepítésének hatását szemlélteti a trópusi éjszakák számának változásával, az egyes időszakokban és szcenáriók szerint.

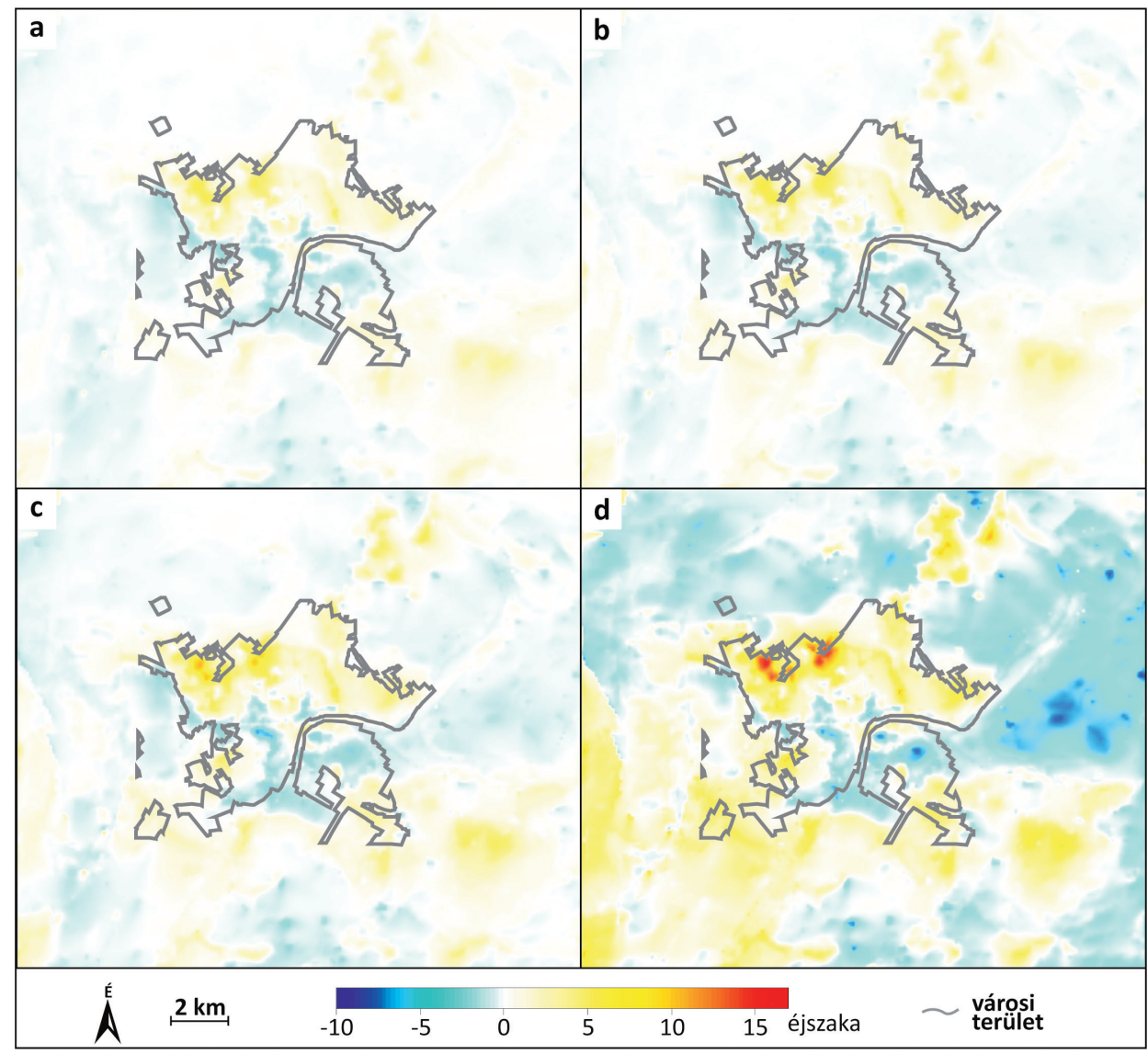

4. ábra A trópusi éjszakák ( $\mathrm{T}_{\min }>20^{\circ} \mathrm{C}$ ) számának különbsége a véderdővel módosított és az eredeti felszínborítású vizsgált területek között (a és b: 2021-2050 RCP4.5 és RCP8.5, c és d: 2071-2100 RCP4.5 és RCP8.5)

Figure 4 The difference in the number of tropical nights $\left(\mathrm{T}_{\min }>20^{\circ} \mathrm{C}\right)$ between the original land use and the one modified by protective forest ( $\mathrm{a}$ and b: 2021-2050 RCP4.5 and RCP8.5, $\mathrm{c}$ and d: 2071-2100 RCP4.5 and RCP8.5) 
A 2021-2050 közötti időszakban a két szcenárió közel azonos eredményt mutat (4.a és b ábra). A trópusi éjszakák számának növekedése leginkább a város északi részében következik be (LCZ 5 és 8), ezen a területen 0 és 5 közötti éjszaka lehet az eltérés. Azonban az északkeleti és északnyugati részeken, több területen akár 5 feletti is lehet ez a szám. A déli városhatár mentén is jelentkezik pozitív eltérés, azonban ez nem akkora mértékú. A véderdő hatására csak a városközpontban várható a trópusi éjszakák csökkenése, ami csupán egy kis területen haladja meg az 5-öt.

A 2071-2100 időszakban az RCP4.5 forgatókönyv szerint kissé nagyobb növekedés mutatkozhat meg a trópusi éjszakák különbségében (4.c ábra). Egyre több területen jelenik meg pozitív különbség az északi városrészben a véderdő hatására. Azoknak a területeknek a nagysága is növekszik, ahol 5 feletti eltérés lehet és több kisebb területen szétszórva akár 10 éjszaka is lehet a különbség. Az RCP8.5 szcenárió szerint jelentősen megnő a trópusi éjszakák száma erre az időszakra, ezért a véderdő telepítésére bekövetkező változás is nagyobb lesz (4.d ábra). Az 5 éjszaka feletti különbség egy kiterjedtebb területet érint az északi városrészben és a város más részein is megjelenik. Északnyugaton, több helyen 10, néhány kisebb területen akár 15 éjszaka feletti is lehet a különbség. A véderdő telepítésének hatására még főként a várostól délre, illetve délnyugatra jelentkezik pozitív eltérés, ezeken a területeken több helyen is meghaladhatja az 5 éjszakát. A belvárosban, a délkeleti városrész egyes területein, valamint a várostól keletre egy nagyobb területen több mint 5 éjszakával csökken a trópusi éjszakák száma.

\section{A klímaindexek számának változása különböző beépítettségü mintaterületeken}

Az előző eredmények alapján a véderdő telepítése a város északi részében eredményezhet jelentôs eltéréseket (3.és 4.ábra). A részletesebb változások megállapítása érdekében ezen a területen mintaterületeket jelöltünk ki különböző beépítésú (LCZ 5, 6 és 8) és a fával telepített (LCZ A) részeken (2.ábra). Ezeken a mintaterületeken külön vizsgáltuk a klímaindexekben bekövetkező változásokat a két szcenárió szerint az egyes időszakokban (2. táblázat).

Látható, hogy a legnagyobb változás valamennyi index esetén az LCZ 8 beépítésnél jelenik meg, ezt követi az LCZ 5, majd az LCZ 6 beépítés (2. táblázat). Az LCZ A borítású területen szinte valamennyi index csökkenése várható, kizárólag a meleg éjszakák értékeinél várható növekedés. Tehát, míg a fás felszínborítás esetén csökken a hőterhelés, a beépített mintaterületek esetén a hőterhelés növekedése várható mindegyik napszakban. A legnagyobb abszolút változás a beépített zónák esetén a meleg éjszakák és a nyári éjszakák, míg az LCZ A-nál a nyári éjszakák és a nyári napok számában történik.

Noha a nappali indexek (nyári és hőségnapok) száma csökken az LCZ A borítású területen, ezzel a kedvezőnek tekinthető hatással közel megegyező mértékben növekszik az LCZ 8 beépítésnél (2.táblázat). Hasonló arányok figyelhetők meg az estét jellemző indexek (sörkerti nap és nyári éjszaka) esetében is. Itt valamennyivel nagyobb a csökkenés az LCZ A-ban, mint a növekedés az LCZ 8-ban, de a különbség elenyészőnek tekinthetô. Azonban az éjszakai indexek (meleg és trópusi éjszaka) esetében azt a minimális változást, ami az LCZ A-ban történik, többszörösen meghaladja a többi zónában bekövetkező növekedés.

\section{Összefoglalás}

Vizsgálatunk alapján a nappali hőmérsékleti viszonyokban a véderdő egy enyhén pozitív változást idézhet elő, mivel kis mértékben csökkentheti a nyári napok és a hőségnapok számát, leginkább a véderdő, illetve a vízfelszínek területén és a belváros egy kis 
2. táblázat - Table 2

A klímaindexek értékeinek átlagos változása az egyes mintaterületeken (2.ábra) a véderdő telepítését követően

The average change in the numbers of climate indices in the sample areas (Figure 2) after the protective forest installation

\begin{tabular}{|c|c|c|c|c|c|c|}
\hline \multirow{2}{*}{ Klímaindex } & \multirow{2}{*}{ Idószak } & \multirow{2}{*}{ Szcenárió } & \multicolumn{4}{|c|}{ Mintaterületek } \\
\hline & & & LCZ 5 & LCZ 8 & LCZ 6 & $\mathrm{LCZ} A$ \\
\hline \multirow{4}{*}{$\begin{array}{l}\text { Nyári nap } \\
\left(\mathrm{T}_{\max }>25^{\circ} \mathrm{C}\right)\end{array}$} & $2021-2050$ & RCP4.5 & 8,5 & 14,9 & 6,2 & $-16,6$ \\
\hline & & RCP8.5 & 8,7 & 15,6 & 6,5 & $-16,8$ \\
\hline & $2071-2100$ & RCP4.5 & 8,2 & 14,6 & 6,3 & $-16,5$ \\
\hline & & RCP8.5 & 7 & 12,8 & 5,3 & $-14,6$ \\
\hline \multirow{4}{*}{$\begin{array}{l}\text { Hőségnap } \\
\left(\mathrm{T}_{\max }>30^{\circ} \mathrm{C}\right)\end{array}$} & $2021-2050$ & $\mathrm{RCP} 4.5$ & 4,3 & 8,1 & 3,4 & $-5,8$ \\
\hline & & RCP8.5 & 4,3 & 8,1 & 3,5 & $-6,3$ \\
\hline & $2071-2100$ & $\mathrm{RCP} 4.5$ & 5 & 9,2 & 3,9 & -8 \\
\hline & & RCP8.5 & 6,4 & 10,7 & 4 & $-12,1$ \\
\hline \multirow{4}{*}{$\begin{array}{l}\text { Sörkerti nap } \\
\left(\mathrm{T}_{20 \mathrm{~h}}>20^{\circ} \mathrm{C}\right)\end{array}$} & $2021-2050$ & $\mathrm{RCP} 4.5$ & 8,4 & 12,6 & 6,2 & -14 \\
\hline & & RCP8.5 & 8,1 & 12,9 & 6,5 & $-14,6$ \\
\hline & $2071-2100$ & $\mathrm{RCP} 4.5$ & 7,1 & 11,4 & 6 & -14 \\
\hline & & RCP8.5 & 6,5 & 10,5 & 5,5 & $-12,6$ \\
\hline \multirow{4}{*}{$\begin{array}{l}\text { Nyári éjszaka } \\
\left(\mathrm{T}_{23 \mathrm{~h}}>20^{\circ} \mathrm{C}\right)\end{array}$} & $2021-2050$ & $\mathrm{RCP} 4.5$ & 9,3 & 17,4 & 8,9 & $-20,2$ \\
\hline & & RCP8.5 & 9,6 & 18 & 9,4 & $-21,7$ \\
\hline & $2071-2100$ & $\mathrm{RCP} 4.5$ & 9,2 & 17,1 & 9,1 & $-19,7$ \\
\hline & & RCP8.5 & 7,8 & 14,7 & 7,8 & $-15,7$ \\
\hline \multirow{4}{*}{$\begin{array}{l}\text { Meleg éjszaka } \\
\left(\mathrm{T}_{\min }>17^{\circ} \mathrm{C}\right)\end{array}$} & $2021-2050$ & $\mathrm{RCP} 4.5$ & 5,7 & 18,4 & 9,4 & 0,1 \\
\hline & & RCP8.5 & 5,6 & 18,4 & 9,8 & $-0,3$ \\
\hline & $2071-2100$ & $\mathrm{RCP} 4.5$ & 5,7 & 18,7 & 9,4 & 0,3 \\
\hline & & RCP8.5 & 5,2 & 16,7 & 7,4 & 1,9 \\
\hline \multirow{4}{*}{$\begin{array}{l}\text { Trópusi éjszaka } \\
\left(\mathrm{T}_{\min }>20^{\circ} \mathrm{C}\right)\end{array}$} & $2021-2050$ & $\mathrm{RCP} 4.5$ & 1,4 & 5,6 & 2,5 & $-1,1$ \\
\hline & & RCP8.5 & 1,7 & 6,6 & 2,9 & $-1,2$ \\
\hline & $2071-2100$ & $\mathrm{RCP} 4.5$ & 2,4 & 8,6 & 3,8 & $-1,4$ \\
\hline & & RCP8.5 & 3,9 & 12,7 & 5,7 & $-0,6$ \\
\hline
\end{tabular}

részén. Azonban a város északi részén, elsősorban az LCZ 5 és 8 beépítéseknél az indexek növekedése várható. Az éjszakai indexek esetében csak a város egy kis részén lehet elenyésző mértékű csökkenés. Ezért Szeged legnagyobb részén a véderdő telepítésének hatására nőhet az éjszakai hőterhelés, leginkább az északnyugati városrészben. Ezeken a területeken az indexek számának növekedése jóval meghaladhatja a más területeken bekövetkezett csökkenést.

Az elemzés rámutat arra, hogy egy ilyen mértékú véderdő telepítése a városi termikus viszonyok egyértelmú romlásával jár. Ezeknek a negatív hatásoknak az oka elsősorban az lehet, hogy az erdősítés miatt a város átszellőzése mérséklődik vagy teljesen blokko- 
lódik, így a helyi, magasabb hőterhelést eredményező hatásokat nem ellensúlyozhatja a külterületek felől érkező beáramlás hútő hatása. Mivel a csökkent ventiláció egyértelmúen tetten érhető a termikus viszonyok alakulásán, ezért feltételezhető, hogy az átszellőzés csökkenése miatt a városokban kibocsátott légszennyezők koncentrációja is növekedhet.

A várt pozitív hatások ellenére tehát alapos tervezés nélkül az ehhez hasonló véderdo"sávok telepítése problémás lehet, hiszen főleg a termikus viszonyok esetén számos negatívum jelenhet meg. Mindazonáltal példaértékú, hogy a hazai várostervezők különböző zöld megoldásokkal igyekeznek a klímaváltozás hatásait enyhíteni. Azonban hangsúlyoznunk kell, hogy a városok esetében a helyi hatásokat is rendkívül fontos felmérni, hiszen bizonyos - mint az ebben a tanulmányban is bemutatott - esetekben a beavatkozások a várakozásokkal pont ellentétes előjelú változásokat eredményezhetnek.

\section{Köszönetnyilvánítás}

A kutatást a Nemzeti Kutatási, Fejlesztési és Innovációs Hivatal (K-137801) támogatta. A felhasznált regionális klímamodell-szimulációkat az EURO-CORDEX projekt biztosította. A MUKLIMO_3 modellhez a Német Időjárási Szolgálat (Deutscher Wetterdienst) biztosította számunkra a hozzáférést.

\section{SKARBIT NóRA}

SZTE Éghajlattani és Tájföldrajzi Tanszék, Szeged skarbitn@geo.u-szeged.hu

UNGER JÁNOS

SZTE Éghajlattani és Tájföldrajzi Tanszék, Szeged unger@geo.u-szeged.hu

\section{GÁL TAMÁs}

SZTE Éghajlattani és Tájföldrajzi Tanszék, Szeged tgal@geo.u-szeged.hu

\section{IRODALOM}

ABDi, B.-HAmi, A.-ZAREHAGHI, D. 2020: Impact of small-scale tree planting patterns on outdoor cooling and thermal comfort. - Sustainable Cities and Society 56. 102085.

Bechtel, B.-Alexander, P. J.-Böhner, J.-Ching, J.-Conrad, O.-Feddema, J. J.-Mills, G.-See, L.-STEWART, I. D. 2015: Mapping local climate zones for a worldwide database of the form and function of cities. - ISPRS International Journal of Geo-Information 4. 1. pp. 199-219.

De Abreu-Harbich, L. V.-LabaKi, L. C.-MatzaraKis, A. 2015: Effect of tree planting design and tree species on human thermal comfort in the tropics. - Landscape and Urban Planning 138. pp. 99-109.

FrüH, B.-Becker, P.-Deutschländer, T.-Hessel J. D.-Kossmann, M.-Mieskes, I.-Namyslo, J.-Roos, M.-Sievers, U.-Steigerwald, T.-Turau, H.-Wienert, U. 2011: Estimation of climate-change impacts on the urban heat load using an urban climate model and regional climate projections. - Journal of Applied Meteorology and Climatology 50. pp. 167-184.

GÁL, T.-MAhÓ, S. I.-SKARBit, N.-UNGER, J. 2021: Numerical modelling for analysis of the effect of different urban green spaces on urban heat load patterns in the present and in the future.-Computers, Environment and Urban Systems 87. 101600.

GÁLOsı-KovÁcs B. 2009: A környezettudatos kistérségfejlesztés kérdései. - Területfejlesztés és Innováció 3. 4. pp. 8-22. 
IPCC 2013: Climate Change 2013: The Physical Science Basis. Contribution of Working Group I to the Fifth Assessment Report of the Intergovernmental Panel on Climate Change [STOCKER, T. F.-QIN, D. - PlatTNER, G.-K.-Tignor, M.-Allen, S. K.-Boschung, J.-Nauels, A.-Xia, Y.-BeX, V.-Midgley, P. M. (eds.)]. Cambridge University Press, Cambridge, UK and New York, NY, USA. 1535 p.

IPCC 2014: Climate Change 2014: Impacts, Adaptation, and Vulnerability. Part B: Regional Aspects. Contribution of Working Group II to the Fifth Assessment Report of the Intergovernmental Panel on Climate Change [Barros, V. R. -Field, C. B.-Dokken, D. J.-Mastrandrea, M. D.-Mach, K. J.-Bilir, T. E.-Chatterjee, M.-Ebi, K. L.-Estrada, Y. O.-Genova, R. C.-Girma, B.-Kissel, E. S.-Levy, A. N.-MacCracken, S.-Mastrandrea, P. R.-White, L. L. (eds.)]. - Cambridge University Press, Cambridge, UK and New York, NY, USA. 688 p.

IPCC 2021: Climate Change 2021: The Physical Science Basis. Contribution of Working Group I to the Sixth Assessment Report of the Intergovernmental Panel on Climate Change [Masson-Delmotte, V.-ZhaI, P.-Pirani, A.-Connors, S. L.-Péan, C.-Berger, S.-Caud, N.-Chen, Y.-Goldfarb, L.-Gomis, M. I.-Huang, M.-Leitzell, K.-Lonnoy, E.-Matthews, J. B. R.-Maycock, T. K. - Waterfield, T.-YelekçI, O.-Yu, R.-Zhou, B. (eds.)]. - Cambridge University Press, Cambridge, UK and New York, NY, USA. In Press.

Jacob, D.-Petersen, J.-Eggert, B.-Alias, A.-Christensen, O. B.-Bouwer, L.-Braun, A.-Colette, A. -Déqué, M.-Georgievski, G.-Georgopoulou, E.-Gobiet, A.-Menut, L.-Nikulin, G.-Haensler, A. -Hempelmann, N.-Jones, C.-Keuler, K.-Kovats, S.-Kröner, N.-Kotlarski, S.-Kriegsmann, A. -Martin, E.-Meijgaard, E.-Moseley, C.-Pfeifer, S.-Preuschmann, S.-Radermacher, C.-Radtke, K.-Rechid, D. - Rounsevell, M.-Samuelsson, P.-Somot, S.-Soussana, J.-F. - Teichmann, C. - ValenTINI, R.-VAUTARD, R.-WEBER, B.-Yiou, P. 2014: EURO-CORDEX: new high-resolution climate change projections for European impact research. - Regional Environmental Change 14. pp. 563-578.

Lehnert, M.-Geletič, J.-HusÁK, J.-Vysoudil, M. 2015: Urban field classification by "local climate zones" in a medium-sized Central European city: the case of Olomouc (Czech Republic). - Theoretical and Applied Climatology 122. pp. 531-541.

Lelovics, E.-Unger, J.-GÁL, T.-GÁL, C. V. 2014: Design of an urban monitoring network based on Local Climate Zone mapping and temperature pattern modelling. - Climate Research 60. pp. 51-62.

MEZŐsI G.-BATA T.-BLANKA V.-LADÁNYI Zs. 2017: A klímaváltozás hatása a környezeti veszélyekre az Alföldön. - Földrajzi Közlemények 141. 1. pp. 60-70.

NowaK, D. J.-CRAne, D. E.-Stevens, J. C. 2006: Air pollution removal by urban trees and shrubs in the United States. - Urban forestry \& urban greening. 4. 3-4. pp. 115-123.

Oke, T. R.-Mills, G.-Christen, A.-Voogt, J. A. 2017: Urban Climates. - Cambridge University Press, Cambridge. 523 p.

Setälä, H.-Virppola, V.-Rantalainen, A. L.-Pennanen, A.-Yli-Pelkonen, V. 2013: Does urban vegetation mitigate air pollution in northern conditions? - Environmental pollution. 183. pp. 104-112.

SIEvERS, U. 2012: Das kleinskalige Strömungsmodell MUKLIMO_3 Teil 1: Theoretische Grundlagen, PC-Basisversion und Validierung. - Berichte des Deutschen Wetterdienstes 240. Offenbach am Main, Germany. $136 \mathrm{p}$.

Sievers, U. 2016: Das kleinskalige Strömungsmodell MUKLIMO_3. Teil 2: Thermodynamische Erwei-terungen. - Berichte des Deutschen Wetterdienstes 248. Offenbach am Main, Germany. 151 p.

SKARBit, N.-GÁL, T. 2016: Projection of intra-urban modification of night-time climate indices during the $21^{\text {st }}$ century. - Hungarian Geographical Bulletin 65. pp. 117-128.

STEWART, I. D.-OKE, T. R. 2012: Local climate zones for urban temperature studies. - Bulletin of the American Meteorological Society 93. 12. pp. 1879-1900.

SÜMEGHY Z.-UNGER J. 2003: A települések hőmérséklet-módosító hatása - a szegedi hősziget-kutatások tükrében. - Földrajzi Közlemények 127. 51.pp. 23-44

TAN, Z.-LAU, K. K. L.-NG, E. 2016: Urban tree design approaches for mitigating daytime urban heat island effects in a high-density urban environment. - Energy and Buildings 114. pp. 265-274.

UnGER J.-GÁL T. 2017: Városklíma. Szeged városklimatológiai vonatkozásai. - Geolitera, Szeged. 256 p.

Unger J.-Lelovics E.-GÁL T.-Mucsi L. 2014: A városi hősziget fogalom finomítása a lokális klímazónák koncepciójának felhasználásával-példák Szegedről. - Földrajzi Közlemények 138. 1. pp. 50-63.

United Nations 2015: World Urbanization Prospects. The 2014 Revisions. - https://esa.un.org./unpd /wup /Publications/Files/WUP2014-Report.pdf

van Vuuren, D. P.-Edmonds, J.-Kainuma, M.-Riahi, K. - Thomson, A.-Hibbard, K. - Hurtt, G. C. - Kram, T.-Krey, V.-Lamarque, J. F.-Masui, T.-Meinshausen, M.-Nakicenovic, N. - Smith, S. J. - Rose, S. K. 2011: The representative concentration pathways: an overview. - Climatic Change 109. pp. 5-31.

WANG, Y.-AKBARI, H. 2016: The effects of street tree planting on Urban Heat Island mitigation in Montreal. - Sustainable Cities and Society 27. pp. 122-128.

YANG, J.-McBride, J.-Zhou, J.-Sun, Z. 2005: The urban forest in Beijing and its role in air pollution reduction. - Urban forestry \& urban greening, 3. 2. pp. 65-78. 
Zhao, Q.-SAILOR, D. J.-WentZ, E. A. 2018: Impact of tree locations and arrangements on outdoor microclimates and human thermal comfort in an urban residential environment. - Urban Forestry \& Urban Greening 32. pp. 81-91.

Žuvela-Aloise, M.-Koch, R.-Neureiter, A.-BöHm, R.-BuchHolz, S. 2014: Reconstructing urban climate of Vienna based on historical maps dating to the early instrumental period. - Urban Climate 10. pp. 490-508.

\section{Internetes források}

[1] Székesfehérvár Megyei Jogú Város Környezetvédelmi Programja 2020-2025 2019: https://www.szekesfehervar.hu/_upload/editor/2019/Onkormanyzat/dukumentumok/kornyezetvedelem/ SZFV_MJV_Kornyezetvedelmi_Program_2020_2025_tervezet.pdf

[2] Hajdú-Bihar Megyei Kormányhivatal Környezetvédelmi és Természetvédelmi Főosztály 2020: Levegőminőségi terv a légszennyezettség javítására Debrecen környéke zónacsoport területén.

https://www.kormanyhivatal.hu/download/c/9e/66000/DEBRECEN\%20levterv_vegleges.pdf 